\title{
The Influence Of Brand Image, Promotion, And Price On Shopee Customer Loyalty (Case Study On Shopee Customers In Karawaci)
}

\author{
Waseso Segoro ${ }^{1 *}$, Sandra Restu Aulia ${ }^{2}$ \\ ${ }^{1,2}$ Faculty of Economics, Gunadarma University, Indonesia \\ "Corresponding Author: \\ Email: waseso@staff.gunadarma.ac.id
}

\begin{abstract}
.
Along with the times, people's lifestyles are increasingly instantaneous because the majority of people have high mobility in their daily activities. So that people are often looking for something practical and instantaneous in meeting their daily needs. Customer loyalty to voluntarily and continuously subscribe to certain companies for a long period of time. This study analyzes brand image, promotion, and price because these three factors play an important role in Shopee customer loyalty. The analytical tools used in this research are validity test, reliability test, normality test, multicollinearity test, heteroscedasticity test, multiple linear regression test, $T$ test (partial), $F$ test (simultaneous) and determination coefficient test using SPSS version 2.0 for windows. The data used are primary data, the respondents in this study were 100 respondents, the sampling technique used was accidental sampling technique.The results showed that partially brand image, promotion, and price have a significant effect on customer loyalty. And simultaneously brand image, promotion, and price have a significant effect on Shopee customer loyalty.
\end{abstract}

Keywords: Brand Image, Promotion, Price, Customer Loyalty

\section{INTRODUCTION}

Advances in technology make it possible to carry out business relationships through a technological device called the internet. In cyberspace, starting in 2014, there have been many social networking applications such as Facebook, Twitter and others that are only for providing information or just uploading photos or videos, but now there are many social applications that make it easier for someone to communicate and even do business.

Fig 1.Data on 10 Indonesian E-commerce Quarter IV / 2019

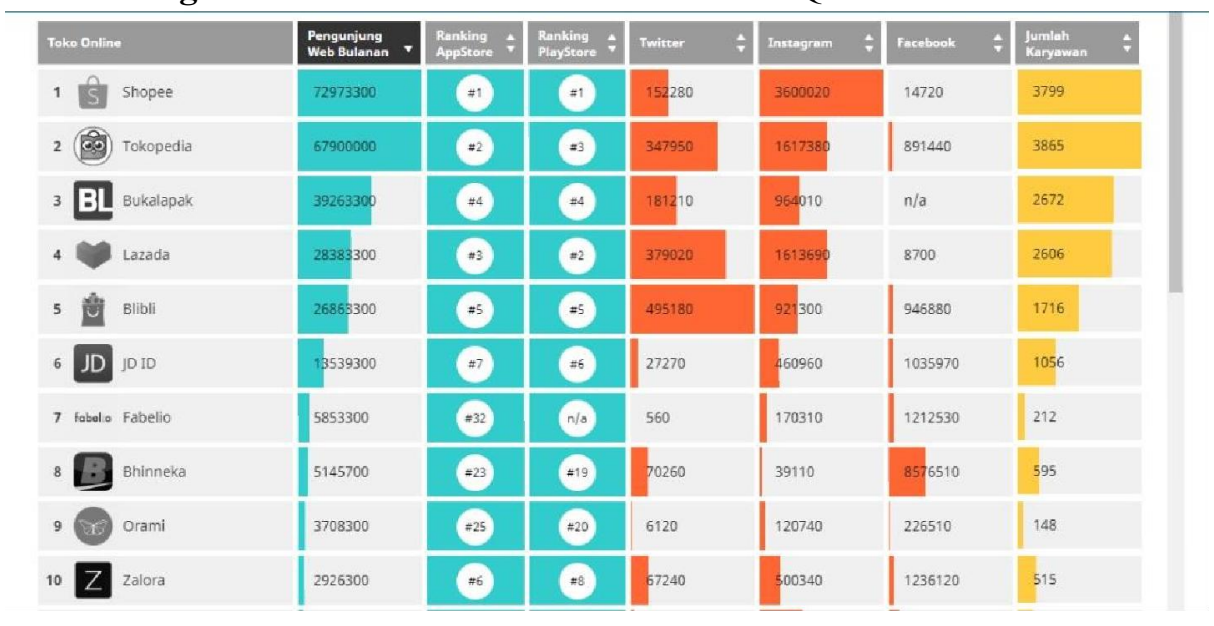

Source: iprice.co.id insights map of e-commerce

Based on the report the latest fourth quarter of 2019 PETA E-commerce Shopee sits atop a commerce which has the highest number of visitors, followed by ecommerce local Tokopedia and bukalapak. This ecommerce made by Chris Feng is able to dominate mobile applications by maintaining its first position as the most popular shopping application on the Android and iOS platforms . 


\section{LITERATURE REVIEW}

\subsection{Brand Image}

According to Rangkuti (2002) " brand image is a set of brand associations formed in the minds of consumers". Brand image is a representation of the overall perception of a brand and is formed from information and knowledge of that brand. The image of the brand is related to the attitude in the form of presentation and preference for a brand.

\subsection{Promotion}

According to Kotler and Keller (2007) promotion is a collection of incentive tools, mostly shortterm, designed to stimulate the faster and greater purchase of a particular product or service by consumers or merchants.

\subsection{Price}

According to Daryanto (2011) price is the amount of money billed for a product or an amount of value exchanged for the benefit of owning or using the product.

\subsection{Customer loyalty}

According to the Pi-Ping Wang and Hsieh-Hong Huang (2011) in general when talking about loyalty meant talking about the intensity of the repurchase (repurchase) and this is the goal of many industries. But if the industry only focuses on customer satisfaction, it will only increase the level of customer satisfaction but decrease the level of customer loyalty.

\subsection{Framework}

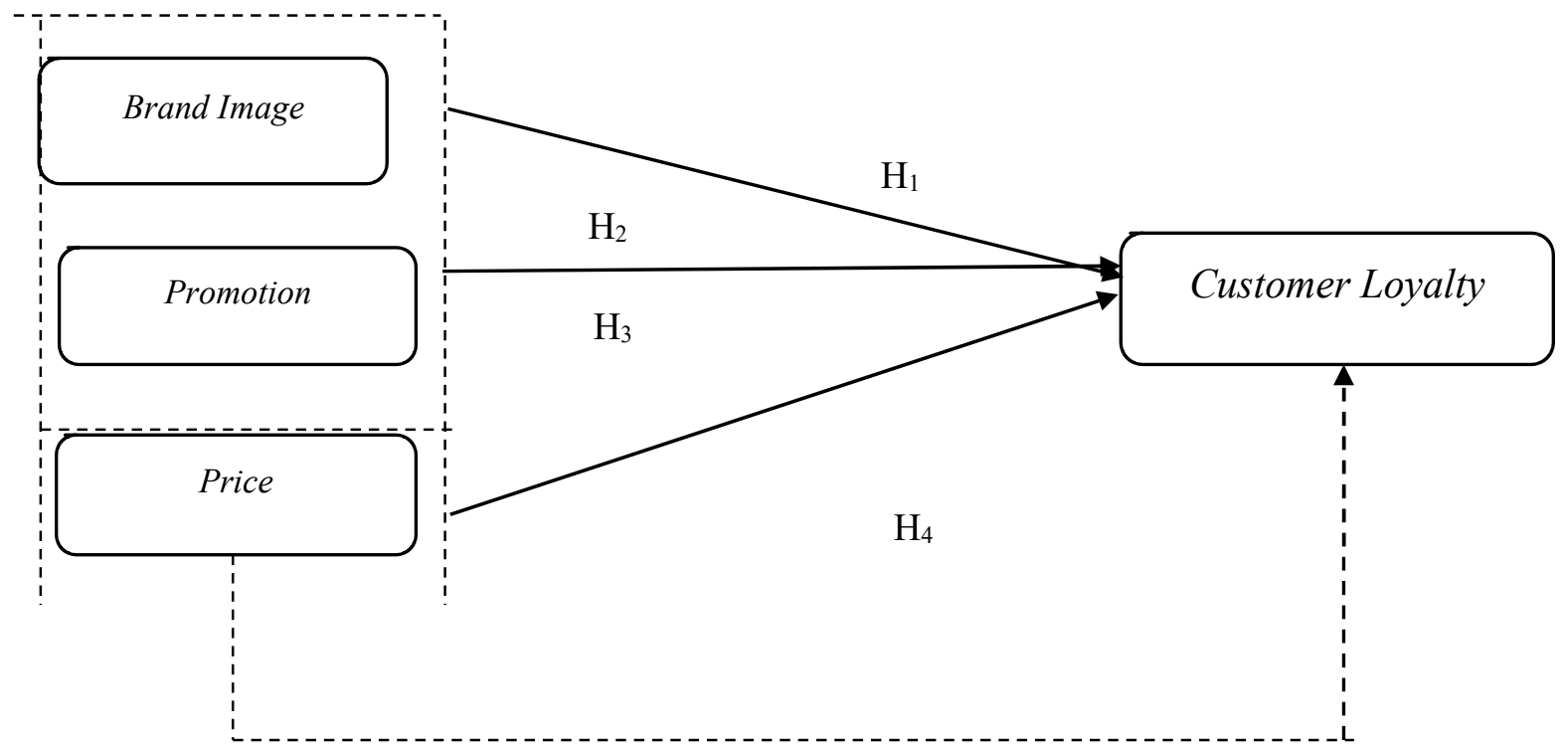

\subsection{Hypothesis}

$\mathrm{H}_{1}$ : Brand image has a significant effect on customer loyalty.

$\mathrm{H}_{2}$ : Promotion has a significant effect on customer loyalty.

$\mathrm{H}_{3}$ : Price has a significant effect on customer loyalty.

$\mathrm{H}_{4}$ : Brand image, promotion, and price have a significant effect on customer loyalty.

\section{METHODS}

\subsection{Types of Data}

The type of data used in this study is primary data. The sampling method used in this study is a nonprobability sampling method with purposive sampling type , to determine a sample with criteria, namely: (1) Have purchased at the Shopee application at least 2 times, (2) Karawaci residents. This person can be used as a sample (respondent) as the basis for data collection. By calculating the sample using the formula Rao Purba (2006) :

$$
n=\frac{Z^{2}}{4(\text { moe })^{2}}
$$


Information:

$\mathrm{n}$ : Number of samples

$\mathrm{Z}$ : Confidence level of sampling $95 \%$ or 1.96

moe : The maximum tolerable error rate, usually $10 \%$

\subsection{Population}

Population is the whole subject and the totality of research subjects can be people, objects, or something that can be obtained and can provide research information (data).

\subsection{Samples}

The sampling technique to determine the sample used in this study is non-probability sampling with purposive sampling type . Purposive sampling is a sampling method that limits the specific characteristics of a person who provides information and is in accordance with what the researcher wants, where the sample is taken based on the criteria of selected respondents, namely residents of Karawaci who have made purchases on the Shopee application at least 2 times.

\subsection{Analysis Tools}

The analysis was carried out using the help of a computer program, namely SPSS ( Statistical Package for Social Science) version 20, the analytical tools used in this study were: validity test, reliability test, normality test, multicolinearity test, heterocedastity test, multiple linear regression test, $\mathrm{T}$ test, $\mathrm{F}$ test, and $\mathrm{R}^{2}$ test .

\section{RESULTS AND DISCUSSION}

\begin{tabular}{|c|c|c|c|}
\hline Hypothesis & Statistic test & Result & Mean \\
\hline $\mathrm{H}_{1}$ Brand Image & $\begin{array}{l}\mathrm{T}_{\text {count }}>\mathrm{T}_{\text {table }} \\
(3,528>1,984) \\
\text { Significant Value }: \\
0.01<0.05\end{array}$ & Influenced & $\begin{array}{l}\text { Brand image is } \\
\text { a series of customer beliefs about } \\
\text { the brand so that the brand } \\
\text { association sticks in the minds of } \\
\text { customers. Brand } \\
\text { Image becomes very important } \\
\text { considered by the company, through } \\
\text { its brand image is good, then it may } \\
\text { cause the value of emotional self- } \\
\text { customers, which will be the } \\
\text { emergence of positive feeling at the } \\
\text { time of purchase or use of a } \\
\text { brand. Conversely, if a brand has a } \\
\text { bad image in the eyes of customers, } \\
\text { it is unlikely that the customer will } \\
\text { remain loyal to the product. }\end{array}$ \\
\hline $\mathrm{H}_{2}$ Promotion & $\begin{array}{l}\mathrm{T}_{\text {count }}>\mathrm{T} \text { table } \\
(2,511>1,984) \\
\text { Significant Value : } \\
0.14<0.05\end{array}$ & Influenced & $\begin{array}{l}\text { This is due to the existence of } \\
\text { advertising media so that customers } \\
\text { are interested in promotions via the } \\
\text { internet, customers are attracted to } \\
\text { discount and cashback programs. }\end{array}$ \\
\hline $\mathrm{H}_{3}$ Price & $\begin{array}{l}\mathrm{T}_{\text {count }}>\mathrm{T}_{\text {table }} \\
(2,372>1,984) \\
\text { Significant Value } \\
0.020<0.05\end{array}$ & Influenced & $\begin{array}{l}\text { The more affordable the price } \\
\text { offered and the price according to } \\
\text { the benefits of the product. Then the } \\
\text { increasing customer loyalty to } \\
\text { Shopee. }\end{array}$ \\
\hline $\begin{array}{l}\mathrm{H}_{4} \text { brand image, } \\
\text { promotion, and } \\
\text { price }\end{array}$ & $\begin{array}{l}\mathrm{F} \text { count }>\mathrm{F} \text { table } \\
7,894>2.70 \\
\text { Significance Value } \\
0.000<0.05\end{array}$ & Influenced & $\begin{array}{l}\text { If brand image, promotion, and } \\
\text { price together have a positive effect } \\
\text { on Shopee customer loyalty, it will } \\
\text { increase. }\end{array}$ \\
\hline
\end{tabular}




\section{CONCLUSION}

Based on the results and discussion of the researchers described in this study, several conclusions have been drawn regarding the effect of brand image, promotion, and price on Shopee customer loyalty, namely:

1. The brand image variable partially influence on Shopee customer loyalty.

2. The promotion variable partially influence Shopee customer loyalty.

3. The price variable partially influence on Shopee customer loyalty.

4. The variables of brand image, promotion, and price simultaneously influence Shopee customer loyalty.

\subsection{Implications}

1. Brand image affects customer loyalty. If someone has a positive impression of a brand, then customer loyalty to Shopee will increase. Companies are advised to increase or strengthen the brand image (brand image) positive by providing or distinguishing characteristic of e-commerce competitors .

2. Promotion has an effect on customer loyalty. This shows that the promotion carried out by the company is in accordance with what the customer wants, so the company must continue to carry out promotions by increasing the discount or free shipping so that customers will remain loyal to make purchases.

3. Price affects customer loyalty. This shows that customers tend to use price as the main indicator to buy, so the more affordable prices set by Shopee and in accordance with benefits, the more loyal customers will be to make purchases.

4. Shopee should do an increase in brand image, promotion, and price together, so it will be more efficient in increasing customer loyalty.

\subsection{Suggestions}

\section{For Companies}

The results of this study state that the price variable has the smallest value. Companies must continue to offer products at affordable prices and price compatibility with quality and benefits, so customers will remain loyal to make purchases. The company also must be able to maintain or increase Shopee customer loyalty. Therefore, companies need to pay attention to factors that can increase customer loyalty such as brand image, promotion, and price.

\section{For Further Researcher}

Further research is suggested to try to add one new variable that has not been used in this research such as service quality, lifestyle, perceived convenience and perception of security. These suggestions are very important in encouraging accuracy of future research results.

\section{REFERENCES}

[1] Daryanto. 2011. Sari Lecture in Marketing Management. Bandung: First printing, PT. Prosperous Conscience Tutorial Tools.

[2] Kotler, Philip \& Lane Keller. 2007. Management Principles. Jakarta: Four Salemba.

[3] Pi, Wan-Ping., Huang, Hsieh-Hong. 2011. "Effects of Promotion on Relationship Quality and Customer Loyalty in the Airline: The Relationship Marketing Approach." African Journal of Business Management Vol 5.

[4] Purba, Rao. 2006. Measuring Consumer Perception Through Factor Analysis. The Asian Manager.

[5] Rangkuti, Freddy. 2002. The Power of Brand: Techniques to Manage Brand Equity and Brand Development Strategy Plus Analysis with SPSS. Jakarta: GramediaPustakaUtama

[6] https://iprice.co.id/insights/mapofecommerce/en/ (Accessed 30 March 2020) 